\title{
Keeping the landscape open - challenges and successful strategies in the Black Forest Biosphere Reserve
}

\section{Christoph Huber, Florian Brossette, Markus Adler \& Walter Kemkes}

Keywords: maintaining the landscape, Allmendweiden, Hinterwälder cattle, Marketing hub, enhancing biodiversity, wild fields, sustainable land-use of mountain pastures

\section{Abstract}

In this policy article, we identify challenges for maintaining the Black Forest Biosphere Reserve's diverse cultural landscape and present the efforts undertaken to address these. Set in a land-use context that is rich in tradition, featuring common pastures and an indigenous cattle breed, landscape preservation today is threatened by fundamental changes in the agricultural community as well as of land-use systems. As part of the MAB network, the UNESCO Black Forest Biosphere Reserve provides collaborative arenas to address these issues and propose action in concertation with local actors and communities. To illustrate this, we describe the ALLMENDE 2.0 applied research project, the creation of a commercialization hub for the local Hinterwälder cattle, and support for the modelling of more extensive ecologically-orientated agriculture.
Profile

Protected area

\section{Black Forest Biosphere}

\section{Reserve}

Mountain range

Low mountain range

Black Forest, Germany

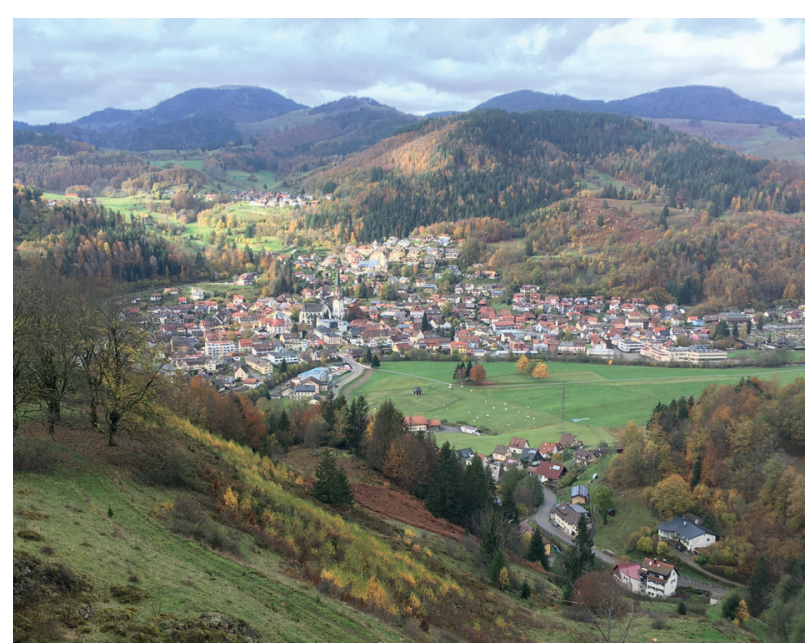

Figure 1 - ALLMENDE in Schönau. (C) Florian Brossette

\section{Introduction}

As the international Man and the Biosphere programme has clearly stated, the UNESCO Biosphere Reserves (BRs) are eminently well qualified to implement measures in line with UNESCO's guidelines. For more than 40 years, BRs have helped to identify ways of addressing user-driven conflicts, and have worked constructively towards general knowledge-based solutions. BRs are specially designated spaces where conflicts will inevitably arise in pursuit of the BRs' aims conflicts between profit orientated economic systems, societal cooperation, and the preservation of natural resources. To resolve the conflicts, sustainable development must be established. This means in real terms that the desire for economic well-being must not be compromised by the preservation of natural resources (and vice versa).
This article focusses on the special features of the landscape within the Black Forest BR and how the area's typical open spaces can be prevented from becoming overgrown. The main role of the BR's staff is supporting local communities and actors to identify challenges, and drawing up successful strategies. Positive examples presented here are an applied research project (ALLMENDE 2.0), the creation of a commercialization hub for the local Hinterwälder cattle, and modelling an ecologically-orientated form of agriculture.

The Black Forest BR (47047'21"N-7 57'27' E) was officially recognized by UNESCO in 2017 and covers more than 63000 ha. The reserve is situated in the centre of the Southern Black Forest and is characterized by mixed mountain forests, colourful flower meadows and pastures, gorges, fens, raised bogs and geological, faunistic and floristic ice age relicts. More than two-thirds of the surface area are covered with near-natural mixed mountain forests; only three per cent of the land are settlement areas. The altitude ranges from $310 \mathrm{~m}$ to peaks of over $1400 \mathrm{~m}$ a.s.l.

\section{Special interest topics}

- Commonly owned grassland

- Forest landscapes and open fields

- Hinterwälder cattle as the special race of the Southern Black Forest

- Commercialization of the Hinterwälder cattle

\section{The Allmendweiden: a form of common pasture}

Allmendweiden (common pastures) are the most important feature of the Black Forest BR. These fields are unique and differentiate the Southern Black For- 
est's landscape from the rest of the mountain chain. The Allmendweiden are large, interconnected areas of extensive pastureland, ranging from valleys to mountaintops. Allmenden were established in the Middle Ages and have been preserved to this day thanks to the local communities' insistence and active communal tradition. Cattle have played a vital role in forming the landscape over the centuries, supported today by goat and sheep herds. The herds have contributed to the creation of the unique biodiversity which exists only in the Black Forest BR.

\section{Hinterwälder cattle: the traditional local breed}

An endemic livestock breed, the Hinterwälder cattle, is the typical and historic race which grazes on the steep slopes of the pastures (Hinterwälder Föderverein e. V. 2020). Their numbers have declined from more than 30000 in the historic Land of Baden in 1900 to just over 2300 in 2018. A special association, the Hinterwälder Zuchtverein, aims to promote the spread of this heritage breed, which was the best choice over centuries due to the cattle's small size and sturdy nature. They weigh up to $480 \mathrm{~kg}$ only, making the most of the relatively poor quality of their grazing, but nevertheless producing milk for many years. Hinterwälder have been bred since 1859, but due to changes in the milk production process, the cattle are now classified as bighly endangered, figuring on the red list of the Society for the Conservation of Old and Domestic Animal Breeds (GEH 2020a,b).

\section{Helping the commercialization of the Hinterwälder cattle}

A specially conducted market study brought to light that the Hinterwälder cattle were suffering from a lack of official recognition, and that the prices paid to farmers were too low for many to maintain the traditional breed. Therefore, a marketing hub was set up by the BR where farmers, chefs and other professionals were brought together to help commercialize the Hinterwälder cattle. In October 2019, over a period of two weeks, more than ten restaurants offered special menus based on the meat of the local breed. The initiative aimed to help preserve the Hinterwälder cattle by helping the farmers to sell their meat at a better price, and by participating in the creation of a regional chain of added value for the benefit of all participants.

The BR team invested greatly in marketing, public relations, setting up logistics and complex communications to ensure networking with all the partners. The logistic chain included selection criteria for the animals, managing their slaughter, processing the meat, and a quality-control system based on sustainability, the welfare of the livestock, and a fair price supported by the Hinterwälder Förder- und Zuchtverein (the association guarding the preservation of the breed).
In 2019 the first culinary Hinterwälder weeks were a success, a success which led to the number of participating chefs doubling, to 21 , for the second iteration of the event. In 2019, eight entire animals were sold. In 2020, 16 head of cattle were processed. As a sideeffect, through close partnership, a growing number of animals are being sold online via the start-up Cowfunding. Here, the consumer can choose which part of the animal he / she wishes to order; care is taken that all parts of the animals' carcasses are properly used. During the Covid-19 pandemic, consumers have been demanding higher-quality products, higher standards in animal welfare, and locally and regionally grown food.

\section{New federal law inspired by forms of culti- vation inside the Biosphere Reserve}

Around 14200 hectares within the BR are cultivated as meadows and pastures, of which around 10000 hectares are extensively used farmland. The small scale of local farming allows cultivation according to recognized ecological criteria or participation in funding programmes for agricultural management, climate protection and animal welfare. Nine out of ten farmers refrain from using artificial fertilizers and pesticides. The outgoing minister for the environment of the federal state of Baden-Wuerttemberg, Franz Untersteller, stated at the start of his biodiversity tour in August 2020 that the BR had been the forerunner for rules implemented in new legislation on enhancing biodiversity for the whole of Baden-Wuerttemberg. Traditionally, farming is not the main occupation of the local agricultural population, more than 90 per cent of whom have another seasonal job or rely on other sources of income, such as tourism.

\section{Wild fields attract interest because of their unique flora and fauna}

Traditional farming on the commonly owned land has survived in the Southern Black Forest to this day. Until the 1960s, the cattle of each individual village were watched by local herdsmen. Then, as elsewhere, the pastures were fenced off. The practices have maintained an active landscape, and the common pastures consist mainly of grassland with large single trees such as pasture beeches (i. e. beeches that have been grazed on by livestock), copses, boulders, scree and rock piles. These wild fields differ greatly from the tame fields in the valley bottoms and attract interest because of their unique flora and fauna, including relicts from the Ice Age.

Some of the plants typically found on the common pastures include Arnica (Arnica montana), Winged broom (Genista sagittalis), Silver thistle (Carlina acaulis), and even Swiss Dandelion (Leontodon helveticus) and Small white orchid (Pseudorchis albida) in the highest areas, which approach a subalpine climate zone. Characteristic animals are Wartbiter (Decticus verrucivorus), 
Table 1 - Findings of ALLMENDE 2.0.

\begin{tabular}{|l|r|}
\hline Parameter & \\
\hline Surface area (ha) & (16\% of Black Forest Biosphere Reserve) \\
\hline Agricultural area (grassland, ha) & 1050 \\
\hline Protected biotopes (ha) & 120 \\
\hline Farm businesses (number) 2016 & (approx. 240 in 1979) \\
\hline $\begin{array}{l}\text { Farms refraining from use of artificial fertilizers/pesticides etc. } \\
\text { (agri-environmental scheme FAKT D1) (number) }\end{array}$ & 98 \\
\hline Organic-certified farm businesses (number) 2019 & Approx. 1540 \\
\hline Bovine animals (heads) November 2019 & Approx. 1000 \\
\hline Goats (heads) 2019 & 67 \\
\hline Share of active farmers > 50 years old (\%) & 1.7 million Euro \\
\hline Agricultural subsidies (EU co-financed measures only) 2018 & (corresponding to approx. 720 Euro/ha/annum) \\
\hline
\end{tabular}

Mountain grasshopper (Stauroderus scalaris), Meadow and Tree pipits (Anthus pratensis and A. trivialis), and fritillary species like the Niobe fritillary (Argynnis niobe).

But this biocenosis is threatened in some parts by the side-effects of insufficient grazing intensity. These species require small open areas of level ground, not overgrown by other plants, and breaks in the vegetation as found on common grassland. One plant on the verge of disappearing is the Mountain Everlasting (Antennaria dioica), which survives only in the highest parts of the BR. The exact causes of its decline are yet to be determined; in 2020, scientists set up a special monitoring and research project to study the question.

\section{ALLMENDE 2.0. - Identifying pathways for sustainable land-use of mountain pastures}

ALLMENDE 2.0. is an applied research project funded by the federal state of Baden-Wuerttemberg and initated by the ministry of the environment. Its objectives are to identify strategies that will enable the long-term maintenance of the open landscape within the Black Forest BR, and to assist farmers and policy makers by creating possible future scenarios. The project is designed to last three years (from spring 2019) and is set in nine small local communities in the Upper Wiesental around Schönau.

The project manager initiated discussions with farmers, local decision makers and scientists. The next step was a thorough analysis of the data available on the land-uses of the common pastures, including agricultural, ecological and socio-economic aspects. The first results are given in Table 1.

Conclusions of the analysis

- The number of part-time farmers has halved in the last 40 years.

- Most of the farms cultivate and maintain between 15 and 30 hectares of grassland.

- Two-thirds of the grassland (mostly pastures) is owned by the local communities, one third (mostly meadows) is private property.
- Most farmers rely on agricultural subsidies for sustaining pastoralism. They use agri-environmental schemes (FAKT) or conclude nature-protection contracts with local communities.

- Two-thirds of active farmers are fifty or older.

- Most of the common pastures are under three levels of protection: EU environmental law (EU Habitats Directive), German federal law and BadenWuerttemberg law.

- Farmers cannot afford modernization of cowsheds because of low income.

- Drought conditions have reduced the quantity of feed available, brought shorter grazing seasons, dried up natural wells on pastures, increased spending on feed, and reduced the numbers of animals which can be fed with natural resources.

How can the Black Forest Biosphere Reserve help to maintain the land-use system?

At the halfway point of the project, in October 2020 , we are testing support measures to assist farmers and land owners:

a. model lease for renting out municipally-owned high nature value grassland;

b. decision-making tool, based on aerial imagery, to deal with unwanted landscape changes (e.g. shrub encroachment) on pastures;

c. framework of common rules and goals for renting out pastures to successors;

d. research on new models and concepts for future part-time farming (including by exploring the perceptions and perspectives of young members of the farming community).

\section{Conclusion}

One of the biggest challenges within the BR and the region is to manage expectations. Often, the natural landscape is taken for granted, but it can only be maintained through the considerable efforts of local communities, farmers and authorities. The preservation of societal structures within the farming and local 
communities will be vital, requiring every support possible. The Biosphere team works in close cooperation with local and regional authorities to bring together people with common interests, attention-worthy ideas, and the will to engage positively in securing the future of structures - societal, agricultural and topographical - that would all otherwise be threatened over time.

\section{References}

Biosphärengebiet Schwarzwald 2019. Geschäftsbericht 2019. Available at: https://www.biosphaerengebietschwarzwald.de/wp-content/uploads / 2020/07/ Gescha\%CC\%88ftsbericht2019_web-1.pdf (accessed: $15 / 10 / 2020)$

Biosphärengebiet Schwarzwald 2020. Projekt ALLMENDE 2.0 - Zwischenbericht: Analyse der Besonderheiten der Landschaftserhaltung im Biosphärengebiet Schwarzwald: 93. Schönau im Schwarzwald Available at: https:// www.biosphaerengebiet-schwarzwald.de/wp-content/uploads/2020/11/Broschuere-ZwischenberichtALLMENDE-2.0-web.pdf (accessed: 09/07/2021)

Biosphärengebiet Schwarzwald 2020. Umweltminister Untersteller im Kleinen Wiesental: Projekte des Biosphärengebiet Schwarzwald vorbildlich für die landesweite Stärkung der Artenvielfalt. Available at: https://www.biosphaerengebiet-schwarzwald.de/pressemitteilungen/ umweltminister-untersteller-im-kleinen-wiesentalprojekte-des-biosphaerengebiet-schwarzwald-vorbildlich-fuer-die-landesweite-staerkung-der-artenvielfalt/ (accessed: 15/10/2020)

Biosphärengebiet Schwarzwald 2020. Kulinarische Hinterwälder Wochen im Biosphärengebiet. Available at: https://www.biosphaerengebiet-schwarzwald.de/ kulinarische-hinterwaelder-wochen/

(accessed: 15/10/2020)

Black Forest Biosphere Reserve 2019. Future and Tradition. 32. Schönau im Schwarzwald.

Brockamp, U., I. Döring-Albrecht, C. Kricke, W. Krögner \& M. Krug 2016. Biosphere Reserve Black Forest - Application for designation as a UNESCO biosphere reserve: 375 . Available at: https://biosphaerengebietschwarzwald.de/wp-content/uploads/2017/12/bsgunesco-engl.pdf (accessed: 15/10/2020)

Bundesumweltministerium 2018. Der Mensch und die Biosphäre, Umsetzung des UNESCO-Programms in Deutschland. Available at: https://www.unesco.de/ sites / default/files/2019-02/mensch_biosphaere_ bf-1.pdf (accessed: 15/10/2020)

GEHa (Gesellschaft zur Erhaltung alter und gefährdeter Haustierrasen e.V. Hinterwälder Rind) 2020a. Hinterwälder Rind. Available at: www.g-e-h.de/index. $\mathrm{php} /$ rassebeschreibungen/34-rassekurzbeschreibungen-rinder/66-hinterwaelder (accessed 15/10/2020)

GEHb (Gesellschaft zur Erhaltung alter und gefährdeter Haustierrasen e.V) 2020b. Rote Liste der bedrobten Nutztierrasen in Deutschland. Available at: www.g-e-h.de/index.php/rote-liste-menu/rote-liste (accessed: 15/10/2020).

Hinterwälder Förderverein e.V. 2020. Hinterwälder...das Urwüchsige aus dem Schwarzwald. Harmonie zwischen Tier und Landschaft. Available at: http:/ / www.hinterwaelder.com (accessed: 15/10/2020)

Schwabe, A. 1990. Veränderungen in montanen Borstgrasrasen durch Düngung und Brachlegung: Antennaria dioica und Vaccinium vitis-idaea als Indikatoren. Tuexenia 10: 295-310. Göttingen.

Schwabe, A., S. Tischew, E. Bergmeier, E. Garve, W. Härdtle, T. Heinken, N. Hölzel, C. Peppler-Lisbach, D. Remy \& H. Dierschke 2019. Pflanzengesellschaft des Jahres 2020: Bordtgrasrasen. Tuexenia 39: 287-308. Göttingen. Available at: https://www.tuexenia.de/wpcontent/uploads/2019/12/14_Tuexenia_39_2019_ Schwabe_et_al.pdf (accessed: 15/10/2020)

\section{Authors}

\section{Christoph Huber}

is a biologist and specialist in nature protection, research and monitoring within the Black Forest Biosphere Reserve. He has long experience in developing concepts for nature protection contracts and in landscape management (for example by removing wood succession), in association with local communities. E-mail: christoph.huber@rpf.bwl.de

\section{Florian Brossette}

has a Master's degree in Agricultural Economics and is project manager of ALLMENDE 2.0. This applied research project seeks to identify strategies to maintain, for the future, an open landscape in the Black Forest Biosphere Reserve. He plans to combine his work at the Biosphere Reserve with a doctoral thesis at the University of Hohenheim. ORCiD ID: https://orcid.org/0000-0002-0485-0921 E-mail: florian.brossette@rpf.bwl.de

\section{Markus Adler}

is Communications Officer within the Black Forest Biosphere Reserve. He has a degree in Politics, History and German, and worked in journalism for almost two decades. Prior to his current post, he was spokesperson for the regional government in Freiburg for five years. E-mail: markus.adler@rpf.bwl.de

\section{Walter Kemkes}

has been the Managing Director of the Black Forest Biosphere Reserve since 2016. After studying Forestry and Biology, he directed the Hainich National Park in Thuringia for ten years before becoming the Managing Director of the Bliesgau Biosphere Reserve. E-mail: walter.kemkes@rpf.bwl.de 